\title{
Evaluation of Stream Flow Network using Entropy Measures of Normal and Lognormal Distributions
}

\author{
N. Vivekanandan
}

\begin{abstract}
Evaluation of stream flow network in any geographical region has utmost importance for planning, design and management of water resources so as to reduce chances of project failure and also to minimize the economic risk. Setting up and maintaining a streamflow network is an evolutionary process, which is need to be reviewed and upgraded periodically to arrive at the optimum network. This paper illustrates the use of entropy measures given by normal and log-normal distributions for evaluation of streamflow network with nine gauging stations of Krishna basin. The study shows that the Pondugala and Wadenapalli stations provided $100 \%$ redundant information, indicating possible discontinuation from the existing network of the basin. The paper presents the methodology adopted in evaluation of streamflow network and the results obtained thereof.

Keywords--- Entropy, Marginal, Network, Stream Flow, Tran Information
\end{abstract}

\section{INTRODUCTION}

$\mathrm{M}$ ONITORING networks established in different river basins collects data on hydrometeorological parameters such as rainfall, streamflow, water quality, sediment, etc; which are required for water resources planning, design and management. Efficient information gathering system should assess the variability in hydrologic processes with spatial and temporal scales and reduce the costs of data collection. Evaluation of network involves determining optimal number of monitoring stations and their respective locations by which hydrological information can be maximized [1-2]. Setting up and maintaining a streamflow network is an evolutionary process, wherein a minimum network is established early in the development of the geographical area; and the network reviewed and upgraded periodically to arrive at an optimum network [3]. For network optimization, approaches commonly used include statistical approaches, user-survey technique, hybrid method and sampling strategies. Statistical approaches for streamflow network optimization range from clustering techniques, spatial regression and entropy-based methods. In this paper, entropy method is used.

Entropy method quantifies the relative information content for the streamflow network and has the advantage that it needs only streamflow data for evaluation. The method facilitates network design by quantifying the marginal contribution of each data collection node to the overall information provided by the network using an index termed as marginal entropy. In

N. Vivekanandan, Assistant Research Officer, Central Water and Power Research Station, Pune.E-mail: anandaan@rediffmail.com recent past, entropy method is widely applied by various researchers for evaluation of different hydrometeorological networks such as streamflow, rainfall, groundwater and water quality monitoring etc., to derive optimum networks. Yang and Burn [4] applied entropy based approach to design stream gauge network for Pembina river basin in southern Manitoba, Canada. They have adopted a directional informational transfer index to identify the most priority station amongst seven stations in the network. Ozkul et al [5] applied the entropy technique for the assessment of water quality monitoring networks for Mississippi River in Louisiana. They concluded that the concept of entropy is a promising method as it quantitatively measures the information produced by network, which will improve the efficiency and costeffectiveness of current monitoring programs.

Markus et al [6] applied entropy and least square methods to evaluate the stream gauging network in the State of Illinois through an assessment of the transferring of information (transinformation) among gauging records for low, average, and high flow conditions. They expressed that the hybrid combination of the entropy and GLS measures of regional value of stations would certainly provide more insight in assessment of stream gauging program and the station rankings based on the combined method can preserve correlation with rankings using both entropy and GLS.

Sarlak and Sorman [7] applied entropy theory to evaluate the streamflow network for Kizihrmak basin. They compared the model uncertainty in streamflow network with transinformation index using normal, log-normal and gamma distributions. They also suggested that the ranking of lognormal distribution could be considered for selection of stream gauge network for Kizihrmak basin. Yoo et al. [8] compared the applications of mixed and continuous distributions in entropy theory to study about the rainfall variability and rainfall intermittency using transinformation index. Their study showed that the mixed distribution is suitable for evaluation of rain gauge network for Choongju basin, Korea.

In this paper, 2-parameter Normal and Log-Normal (N2 and LN2) distributions are used for computation of entropy values for the stations under consideration. Transinformation index measures the redundant or mutual information between variables, and is computed from marginal and conditional entropy indices to derive an optimum network. The methodology adopted in evaluation of streamflow network of Krishna basin using entropy measures of N2 and LN2 are briefly described in the following sections. 


\section{Methodology}

The main objective of evaluating a data collection network is to identify the stations that are producing redundant or repeated information; which can be measured quantitatively by computing transinformation or the redundancy produced by each station in the network.

\section{A. Concept of Entropy}

A quantitative measure of the uncertainty associated with a probability distribution, or the information content of the distributions termed Shannon entropy [9], can be expressed as:

$$
\mathrm{H}(\mathrm{X})=-\mathrm{k} \sum \mathrm{p}_{\mathrm{i}} \ln \left(\mathrm{p}_{\mathrm{i}}\right)
$$

Where, $\mathrm{H}(\mathrm{X})$ is the entropy corresponding to the random variable $\mathrm{X} ; \mathrm{k}$ is a constant that has value equal to one, when natural logarithm is taken; and pi represents the probability of ith event of random variable $\mathrm{X}$.

\section{B. Marginal Entropy}

Marginal entropy for the discrete random variable $\mathrm{X}$ is defined as:

$$
\mathrm{H}(\mathrm{X})=-\mathrm{k} \sum_{\mathrm{i}=1}^{\mathrm{N}} \mathrm{p}\left(\mathrm{X}_{\mathrm{i}}\right) \ln \left(\mathrm{p}\left(\mathrm{X}_{\mathrm{i}}\right)\right)
$$

where, $\mathrm{p}(\mathrm{Xi})$ is the probability of occurrence of $\mathrm{Xi}$, computed either by $\mathrm{N} 2$ or LN2 distribution, and $\mathrm{N}$ is the number of observations. The marginal entropy $\mathrm{H}(\mathrm{X})$ indicates the amount of information or uncertainty that $X$ has. If the variables $\mathrm{X}$ and $\mathrm{Y}$ are independent, then the joint entropy $[\mathrm{H}(\mathrm{X}, \mathrm{Y})]$ is equal to the sum of their marginal entropies defined by:

$$
\mathrm{H}(\mathrm{X}, \mathrm{Y})=\mathrm{H}(\mathrm{X})+\mathrm{H}(\mathrm{Y})
$$

If the variables are stochastically dependent, then the joint entropy is less than its total entropy.

\section{Conditional Entropy}

Conditional entropy measures the entropy of a random variable $\mathrm{Y}$, if one has already learned completely about the random variable $\mathrm{X}$. The conditional entropy of $\mathrm{Y}$ on $\mathrm{X}$ is defined by:

$$
\mathrm{H}(\mathrm{Y} / \mathrm{X})=\mathrm{H}(\mathrm{X}, \mathrm{Y})-\mathrm{H}(\mathrm{X})
$$

Conditional entropy value becomes zero, if the value of one variable is completely determined by the value of other variable. If the variables are independent, then $\mathrm{H}(\mathrm{Y} / \mathrm{X})=\mathrm{H}(\mathrm{Y})$.

\section{Trans Information Index}

Tran information is the form of entropy that measures the redundant or mutual information between variables. Transinformation represents the amount of information, which is common to two stochastically dependent variables $\mathrm{X}$ and $\mathrm{Y}$. The transinformation between $\mathrm{X}$ and $\mathrm{Y}$ is defined as:

$$
\mathrm{T}(\mathrm{X}, \mathrm{Y})=\mathrm{H}(\mathrm{X})+\mathrm{H}(\mathrm{Y})-\mathrm{H}(\mathrm{X}, \mathrm{Y})=\mathrm{H}(\mathrm{Y})-\mathrm{H}(\mathrm{Y} \mid \mathrm{X})
$$

For independent $\mathrm{X}$ and $\mathrm{Y}, \mathrm{T}(\mathrm{X}, \mathrm{Y})=0$. The value of $\mathrm{T}(\mathrm{X}$, $\mathrm{Y})$ is also known as transinformation index [10].

\section{E. Steps Involved in Computation of Entropy Measures}

In practice, the existing sampling sites of a streamflow network can be arranged in the order of information content. In the ordered list thus obtained, the first station is the one where the highest uncertainty about the variable occurs, and the subsequent stations serve to reduce the uncertainty further [11]. The steps involved in selecting the best combination of stations using entropy method are as follows:

1. Let the data collection network under review, consists of $\mathrm{M}$ monitoring stations. The data series of the variable of interest at each station $\left(\mathrm{X}_{1}, \mathrm{X}_{2}, \ldots, \mathrm{X}_{\mathrm{M}}\right)$ is represented by $\mathrm{X}_{\mathrm{ij}}$, where ' $\mathrm{i}$ ' denotes the station identification number $(i=1,2, \ldots, M)$ and ' $\mathrm{j}$ ' is for time period $(\mathrm{j}=1,2, \ldots, \mathrm{N})$. The data length at all stations is assumed to be equal to $\mathrm{N}$. The best fitted multivariate joint probability density function for the subset $\left(X_{1}\right.$, $\mathrm{X}_{2}, \ldots, \mathrm{X}_{\mathrm{M}}$ ) of M monitoring stations is selected.

2. The marginal entropy of the variable $H\left(X_{i}\right)$ $(\mathrm{i}=1,2, \ldots, \mathrm{M})$ for each station is calculated. The station with the highest marginal entropy is denoted as the first priority station $\operatorname{Pr}\left(X z_{1}\right)$. This is the location, where the highest uncertainty occurs about the variable and hence information-gain will be highest from the observations recorded at this site.

3. This station $\operatorname{Pr}\left(\mathrm{Xz}_{1}\right)$ is coupled with every other (M-1) stations in the network to compute transinformation $\mathrm{T}\left(\mathrm{X}_{\mathrm{i}}, \operatorname{Pr}\left(X \mathrm{X}_{1}\right)\right)$ with $\mathrm{X}_{\mathrm{i}} \neq \operatorname{Pr}\left(\mathrm{Xz} \mathrm{z}_{1}\right), \mathrm{i}=1,2, \ldots \mathrm{M}$; and to select that pair, which gives the least transinformation. The station that fulfils this condition is marked as the second priority location $\operatorname{Pr}\left(\mathrm{Xz}_{2}\right)$.

4. The pair $\left(\operatorname{Pr}\left(X z_{1}\right), \operatorname{Pr}\left(X_{2}\right)\right)$ is coupled with every other (M-2) station in the network to select a triplet with the least transinformation $\mathrm{T}\left(\mathrm{X}_{\mathrm{i}} ; \operatorname{Pr}\left(\mathrm{Xz}_{1}\right), \operatorname{Pr}\left(\mathrm{Xz}_{2}\right)\right)$. The same procedure is continued by successively considering combinations of three and more stations, and selecting the combination that produces the least transinformation. Finally, all $\mathrm{M}$ monitoring stations $\left(\mathrm{X}_{1}, \mathrm{X}_{2}, \ldots, \mathrm{X}_{\mathrm{M}}\right)$ can be ranked in priority order to get $\left(\operatorname{Pr}\left(\mathrm{Xz}_{1}\right), \operatorname{Pr}\left(\mathrm{Xz}_{2}\right), \ldots, \operatorname{Pr}\left(\mathrm{Xz}_{\mathrm{M}}\right)\right)$.

5. It is possible to terminate the above process early, before carrying out for all $\mathrm{M}$ stations by selecting a particular threshold transinformation value as the amount of redundant information to be permitted in the network, such that sampling of the variable may be stopped at the stations that exceed the threshold to get optimum number of stations, which is less than $\mathrm{M}$.

In the above procedure, the benefits for each combination of sampling sites are measured in terms of least transinformation or the highest conditional entropy produced by that combination. The above procedure helps to assess network configurations with respect to the existing stations. If new stations are to be added to the system, their locations may be selected again on the basis of the entropy method by ensuring maximum gain of information. The correlation coefficient of each monitoring station can be computed by using Eq. (6) based on transinformation index.

$$
\text { Trans information }(\mathrm{T})=-\frac{1}{2} \ln \left(1-\mathrm{R}^{2}\right)
$$

Where $\mathrm{R}$ represents the multiple correlation coefficient of $X_{\mathrm{i}}$ on $\operatorname{Pr}\left(\mathrm{Xz}_{1}\right), \operatorname{Pr}\left(\mathrm{Xz}_{2}\right), \ldots, \operatorname{Pr}\left(\mathrm{Xz}_{\mathrm{M}}\right)$. 


\section{APPLICATION}

The entropy based method is applied to evaluate the streamflow network of Krishna river basin consisting of nine stream gauge stations. The Krishna river basin is located in southern India lies between latitudes $13^{\circ} 05^{\prime} \mathrm{N}$ to $19^{\circ} 20^{\prime} \mathrm{N}$ and longitudes $73^{\circ} 15^{\prime} \mathrm{E}$ to $81^{\circ} 20^{\prime} \mathrm{E}$. The river originates in the Western Ghats at an elevation of about $1337 \mathrm{~m}$ just north of Mahabaleshwar, about $64 \mathrm{~km}$ from the Arabian Sea, and flows towards east for about $1400 \mathrm{~km}$ before falling into the Bay of Bengal. The geographical area of the basin is 258948 $\mathrm{km} 2$, being partly in the states of Andhra Pradesh (76252 $\left.\mathrm{km}^{2}\right)$, Karnataka $\left(113271 \mathrm{~km}^{2}\right)$ and Maharashtra $\left(69425 \mathrm{~km}^{2}\right)$. The principal tributaries joining Krishna are Ghataprabha, Malaprabha, Bhima, Tungabhadra, Vedavathi and Musi. The average annual rainfall is varying from $300 \mathrm{~mm}$ to $1000 \mathrm{~mm}$ [12]. Streamflow data recorded at Arjunwad, Galgali, Huvinhedgi, Karad, Krishna Agraharam, Kurundwad, Pondugala, Vijayawada and Wadenapalli stations for the period 1981-2001 are used.

\section{RESUlTS AND Discussions}

By applying the procedure detailed above, a computer program was developed and used to compute the transinformation index from marginal and conditional entropy values. The program identifies the first priority station based on marginal entropy; computes the conditional entropy with reference to first priority station; and arranges the stream gauge stations in order of priority based on transinformation index. Table 1 gives the model parameters and marginal entropy values given by $\mathrm{N} 2$ and LN2 distributions for nine stream gauge stations of Krishna river basin considered in the study.

From Table 1, it transpires that Vijayawada station is the first priority station based on marginal entropy values given by N2 and LN2 distributions. The station is coupled with other eight stations individually to identify the next priority station in order, and to compute the transinformation index. Tables 2 and 3 give the transinformation index matrix obtained by using N2 and LN2 for the stations under study. Tables 4 and 5 give the details on redundant information passed by each station based on transinformation index and its corresponding correlation coefficient values given by $\mathrm{N} 2$ and LN2 distributions.
Table 1: Parameters and Marginal Entropy Values given by N2 and LN2 Distributions

\begin{tabular}{|c|c|c|c|c|c|c|c|}
\hline \multirow{3}{*}{$\begin{array}{l}\text { S. } \\
\text { N } \\
\text { o. }\end{array}$} & \multirow{3}{*}{$\begin{array}{c}\text { Gauging } \\
\text { station }\end{array}$} & \multicolumn{4}{|c|}{ Parameters } & \multirow{2}{*}{\multicolumn{2}{|c|}{$\begin{array}{c}\text { Marginal } \\
\text { entropy }\end{array}$}} \\
\hline & & \multicolumn{2}{|c|}{$\mathrm{N} 2$} & \multicolumn{2}{|c|}{ LN2 } & & \\
\hline & & $\begin{array}{c}\mu_{\mathrm{x}} \\
\left(10^{3}\right. \\
\left.\mathrm{m}^{3} / \mathrm{s}\right) \\
\end{array}$ & $\begin{array}{c}\sigma_{\mathrm{x}} \\
\left(10^{3}\right. \\
\left.\mathrm{m}^{3} / \mathrm{s}\right)\end{array}$ & $\mu_{\mathrm{y}}$ & $\sigma_{\mathrm{y}}$ & $\mathrm{N} 2$ & LN2 \\
\hline 1 & Vijayawa & $\begin{array}{c}216.9 \\
27\end{array}$ & $\begin{array}{c}141.3 \\
58\end{array}$ & $\begin{array}{c}12.03 \\
0\end{array}$ & 0.80 & $\begin{array}{c}13.27 \\
8\end{array}$ & 1.20 \\
\hline \multirow[t]{2}{*}{2} & Krishna & 295.1 & 120.0 & 12.51 & 0.41 & 11.47 & 0.53 \\
\hline & $\begin{array}{c}\text { Agrahara } \\
\mathrm{m}\end{array}$ & 21 & 78 & 5 & 1 & 6 & 1 \\
\hline \multirow[t]{2}{*}{3} & Huvinhed & 192.6 & 73.36 & 12.09 & 0.38 & 12.63 & 0.47 \\
\hline & gi & 13 & 2 & 9 & 8 & 4 & 2 \\
\hline \multirow[t]{2}{*}{4} & Galgali & 173.2 & 74.22 & 11.99 & 0.37 & 11.97 & 0.42 \\
\hline & & 64 & 5 & 2 & 1 & 1 & 8 \\
\hline \multirow[t]{2}{*}{5} & Kurundw & 118.8 & 43.59 & 11.62 & 0.36 & 12.10 & 0.41 \\
\hline & $\mathrm{ad}$ & 74 & 4 & 3 & 5 & 2 & 1 \\
\hline \multirow[t]{2}{*}{6} & Arjunwad & 80.07 & 38.24 & 11.19 & 0.44 & 13.11 & 0.60 \\
\hline & & 6 & 9 & 5 & 4 & 5 & 6 \\
\hline \multirow[t]{2}{*}{7} & Karad & 48.73 & 23.31 & 10.70 & 0.41 & 12.62 & 0.52 \\
\hline & & 1 & 6 & 6 & 0 & 2 & 8 \\
\hline \multirow[t]{2}{*}{8} & Wadenap & 224.5 & 115.0 & 12.19 & 0.53 & 13.26 & 0.79 \\
\hline & alli & 17 & 01 & 0 & 7 & 3 & 7 \\
\hline \multirow[t]{2}{*}{9} & Pondugal & 254.7 & 139.2 & 12.29 & 0.58 & 13.07 & 0.87 \\
\hline & $\mathrm{a}$ & 68 & 96 & 5 & 2 & 2 & 7 \\
\hline
\end{tabular}

$\mu_{\mathrm{x}}$ and $\sigma_{\mathrm{x}}$ are mean and standard deviation of the recorded annual average flow; $\mu_{\mathrm{y}}$ and $\sigma_{\mathrm{y}}$ are mean and standard deviation of the log-transformed data of annual average flow

Table 2: Tran's Information Index Matrix Based on Marginal Entropy Using N2 Distribution

\begin{tabular}{|c|c|c|c|c|c|c|c|c|}
\hline \multirow{2}{*}{$\begin{array}{l}\text { Gauging } \\
\text { station }\end{array}$} & \multicolumn{8}{|c|}{ Transinformation index $(\mathrm{T})$ values given by $\mathrm{N} 2$ at } \\
\hline & S2 & S3 & S4 & S5 & S6 & S7 & S8 & S9 \\
\hline $\begin{array}{c}\text { Vijayawa } \\
\text { da }\end{array}$ & - & - & - & - & - & - & - & - \\
\hline Krishna & 0.69 & 0.72 & 0.64 & 0.66 & 0.66 & - & - & - \\
\hline $\begin{array}{c}\text { Agrahara } \\
\text { m }\end{array}$ & 3 & 2 & 9 & 0 & 7 & & & \\
\hline $\begin{array}{l}\text { Huvinhed } \\
\text { gi }\end{array}$ & $\begin{array}{c}0.65 \\
3\end{array}$ & $\begin{array}{c}0.61 \\
6\end{array}$ & $\begin{array}{c}0.68 \\
8\end{array}$ & $\begin{array}{c}0.68 \\
3\end{array}$ & $\begin{array}{c}0.70 \\
7\end{array}$ & $\begin{array}{c}0.71 \\
9\end{array}$ & - & - \\
\hline Galgali & $\begin{array}{c}0.31 \\
5\end{array}$ & $\begin{array}{c}0.29 \\
6\end{array}$ & - & - & - & - & - & - \\
\hline $\begin{array}{c}\text { Kurundw } \\
\text { ad }\end{array}$ & $\begin{array}{c}0.42 \\
8\end{array}$ & $\begin{array}{c}0.41 \\
4\end{array}$ & $\begin{array}{c}0.45 \\
7\end{array}$ & $\begin{array}{c}0.45 \\
8\end{array}$ & - & - & - & - \\
\hline Arjunwad & $\begin{array}{c}0.41 \\
1\end{array}$ & $\begin{array}{c}0.39 \\
6\end{array}$ & $\begin{array}{c}0.43 \\
5\end{array}$ & - & - & - & - & - \\
\hline Karad & $\begin{array}{c}0.29 \\
3\end{array}$ & - & - & - & - & - & - & - \\
\hline $\begin{array}{c}\text { Wadenap } \\
\text { alli }\end{array}$ & $\begin{array}{c}1.30 \\
6\end{array}$ & $\begin{array}{c}1.24 \\
2\end{array}$ & $\begin{array}{c}1.22 \\
9\end{array}$ & $\begin{array}{c}1.27 \\
2\end{array}$ & $\begin{array}{c}1.35 \\
4\end{array}$ & $\begin{array}{c}1.35 \\
5\end{array}$ & $\begin{array}{c}1.34 \\
4\end{array}$ & $\begin{array}{c}1.35 \\
3\end{array}$ \\
\hline $\begin{array}{c}\text { Pondugal } \\
\mathrm{a}\end{array}$ & $\begin{array}{c}1.24 \\
6\end{array}$ & $\begin{array}{c}1.18 \\
0\end{array}$ & $\begin{array}{c}1.20 \\
0\end{array}$ & $\begin{array}{c}1.22 \\
1\end{array}$ & $\begin{array}{c}1.24 \\
2\end{array}$ & $\begin{array}{c}1.29 \\
4\end{array}$ & $\begin{array}{c}1.27 \\
9\end{array}$ & - \\
\hline $\begin{array}{r}\text { Note: S } \\
\text { comput } \\
\text { entropy o } \\
\text { table, th } \\
\text { each step }\end{array}$ & $\begin{array}{l}\text { first } \\
\text { stati } \\
\text { s cor }\end{array}$ & hav & $\begin{array}{l}\ldots, 9) \\
\text { aform } \\
\text { station } \\
\text { g the } \\
\text { as the } \\
\quad 0\end{array}$ & $\begin{array}{l}\text { ast } \\
\text { lext } \\
\text { e. }\end{array}$ & $\begin{array}{l}\text { y V } \\
\text { nsin } \\
\text { iorit }\end{array}$ & $\begin{array}{l}\text { teps } \\
\text { sed } \\
\text { yaw } \\
\text { rmat } \\
\text { static }\end{array}$ & $\begin{array}{l}\text { olve } \\
\text { marg } \\
\text { Fro } \\
\text { ind } \\
\text { to the }\end{array}$ & $\begin{array}{l}\text { in } \\
\text { al } \\
\text { the } \\
\text { at } \\
\text { irst }\end{array}$ \\
\hline
\end{tabular}


Table 3: Trans Information Index Matrix based on Marginal Entropy using LN2 Distribution

\begin{tabular}{|c|c|c|c|c|c|c|c|c|}
\hline \multirow{2}{*}{$\begin{array}{l}\text { Gauging } \\
\text { station }\end{array}$} & \multicolumn{8}{|c|}{ Transinformation index (T) values given by LN2 at } \\
\hline & S2 & S3 & S4 & S5 & S6 & S7 & S8 & S9 \\
\hline $\begin{array}{c}\text { Vijayawa } \\
\text { da }\end{array}$ & - & - & - & - & - & - & - & - \\
\hline $\begin{array}{c}\text { Krishna } \\
\text { Agrahara } \\
\text { m }\end{array}$ & $\begin{array}{c}0.00 \\
9\end{array}$ & $\begin{array}{c}0.08 \\
1\end{array}$ & $\begin{array}{c}0.09 \\
7\end{array}$ & $\begin{array}{c}0.11 \\
4\end{array}$ & - & - & - & - \\
\hline $\begin{array}{l}\text { Huvinhed } \\
\text { gi }\end{array}$ & $\begin{array}{c}0.00 \\
2\end{array}$ & - & - & - & - & - & - & - \\
\hline Galgali & $\begin{array}{c}0.08 \\
8\end{array}$ & $\begin{array}{c}0.19 \\
3\end{array}$ & $\begin{array}{c}0.20 \\
2\end{array}$ & $\begin{array}{c}0.20 \\
3 \\
\end{array}$ & $\begin{array}{c}0.20 \\
9 \\
\end{array}$ & $\begin{array}{c}0.24 \\
5\end{array}$ & - & - \\
\hline $\begin{array}{c}\text { Kurundw } \\
\text { ad }\end{array}$ & $\begin{array}{c}0.00 \\
8\end{array}$ & $\begin{array}{c}0.07 \\
9\end{array}$ & - & - & - & - & - & - \\
\hline Arjunwad & $\begin{array}{c}0.01 \\
6\end{array}$ & $\begin{array}{c}0.08 \\
0\end{array}$ & $\begin{array}{c}0.08 \\
2\end{array}$ & - & - & - & - & - \\
\hline Karad & $\begin{array}{c}0.07 \\
6\end{array}$ & $\begin{array}{c}0.11 \\
3\end{array}$ & $\begin{array}{c}0.11 \\
3\end{array}$ & $\begin{array}{c}0.12 \\
6\end{array}$ & $\begin{array}{c}0.13 \\
1\end{array}$ & - & - & - \\
\hline $\begin{array}{l}\text { Wadenap } \\
\text { alli }\end{array}$ & $\begin{array}{c}0.00 \\
3\end{array}$ & $\begin{array}{c}0.18 \\
2\end{array}$ & $\begin{array}{c}0.25 \\
4\end{array}$ & $\begin{array}{c}0.25 \\
6\end{array}$ & $\begin{array}{c}0.26 \\
5\end{array}$ & $\begin{array}{c}0.31 \\
8\end{array}$ & $\begin{array}{c}0.32 \\
8\end{array}$ & - \\
\hline $\begin{array}{c}\text { Pondugal } \\
\text { a }\end{array}$ & $\begin{array}{c}0.00 \\
3\end{array}$ & $\begin{array}{c}0.19 \\
5\end{array}$ & $\begin{array}{c}0.29 \\
0\end{array}$ & $\begin{array}{c}0.29 \\
0\end{array}$ & $\begin{array}{c}0.31 \\
4\end{array}$ & $\begin{array}{c}0.39 \\
4\end{array}$ & $\begin{array}{c}0.41 \\
8\end{array}$ & $\begin{array}{c}0.41 \\
8\end{array}$ \\
\hline
\end{tabular}

Table 4: Details of Trans Information Index, Redundant Information and Correlation Coefficient for Different Stations of Krishna Basin Using N2 Distribution

\begin{tabular}{|c|c|c|c|}
\hline $\begin{array}{c}\text { Gauging } \\
\text { station } \\
\text { (Based on } \\
\text { priority rank) }\end{array}$ & $\begin{array}{c}\text { Transinformation } \\
\text { index (T) }\end{array}$ & $\begin{array}{c}\text { Redundant } \\
\text { information } \\
{\left[(\mathrm{T} / 1.353)^{*} 100\right]}\end{array}$ & $\begin{array}{c}\text { Correlation } \\
\text { coefficient } \\
{[1 \text {-Exp(- }} \\
2 \mathrm{~T})]^{0.5}\end{array}$ \\
\hline Karad & 0.293 & 21.7 & 0.666 \\
\hline Galgali & 0.296 & 21.9 & 0.668 \\
\hline Arjunwad & 0.435 & 32.2 & 0.762 \\
\hline Kurundwad & 0.458 & 33.9 & 0.775 \\
\hline $\begin{array}{c}\text { Krishna } \\
\text { Agraharam }\end{array}$ & 0.667 & 49.3 & 0.858 \\
\hline Huvinhedgi & 0.719 & 53.1 & 0.873 \\
\hline Pondugala & 1.279 & 94.5 & 0.960 \\
\hline Wadenapalli & 1.353 & 100.0 & 0.966 \\
\hline
\end{tabular}

Table 5: Details of Trans Information Index, Redundant Information and Correlation Coefficient for Different Stations of Krishna Basin using LN2 Distribution

\begin{tabular}{|c|c|c|c|}
\hline $\begin{array}{c}\text { Gauging station } \\
\text { (Based on } \\
\text { priority rank) }\end{array}$ & $\begin{array}{c}\text { Transinform } \\
\text { ation } \\
\text { index (T) }\end{array}$ & $\begin{array}{c}\text { Redundant } \\
\text { information } \\
{\left[(\mathrm{T} / 0.418)^{* 1}\right.} \\
00]\end{array}$ & $\begin{array}{c}\text { Correlation } \\
\text { coefficient } \\
{[1-\operatorname{Exp}(-2 \mathrm{~T})]^{0.5}}\end{array}$ \\
\hline Huvinhedgi & 0.002 & 0.5 & 0.063 \\
\hline Kurundwad & 0.079 & 18.9 & 0.382 \\
\hline Arjunwad & 0.082 & 19.6 & 0.389 \\
\hline $\begin{array}{c}\text { Krishna } \\
\text { Agraharam }\end{array}$ & 0.114 & 27.3 & 0.452 \\
\hline Karad & 0.131 & 31.3 & 0.480 \\
\hline Galgali & 0.245 & 58.6 & 0.622 \\
\hline Wadenapalli & 0.328 & 78.5 & 0.694 \\
\hline Pondugala & 0.418 & 100.0 & 0.753 \\
\hline
\end{tabular}

Figures 1 and 2 give the diagrammatic representation of transinformation index and correlation coefficient given by $\mathrm{N} 2$ and LN2 distributions for eight stations other than first priority station, namely, Vijayawada. From Tables 4 and 5, it may be noted that Wadenapalli station provides $100 \%$ redundant information when N2 is used and Pondugala station provides $100 \%$ redundant information when LN2 is used, as indicated by the transinformation index value; and considered as the reference station for computation of redundant information for other stations. Also, from Tables 4 and 5, it may noted that the amount of redundant information passed by the stations other than Pondugala and Wadenapalli varied from about $22 \%$ to $53 \%$ when N2 is used; and about $1 \%$ to $59 \%$ when $\mathrm{LN} 2$ is used. Figure 3 shows the percentage of redundant information passed by each station computed from transinformation index values given by $\mathrm{N} 2$ and $\mathrm{LN} 2$ distributions.

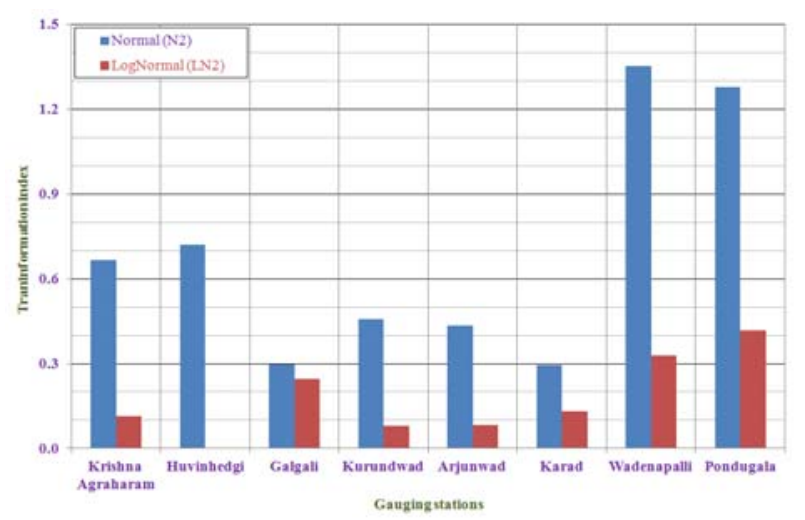

Figure 1: Trans Information Index of Gauging Stations with Reference to First Priority Station (Vijayawada) given by N2 and LN2 Distributions

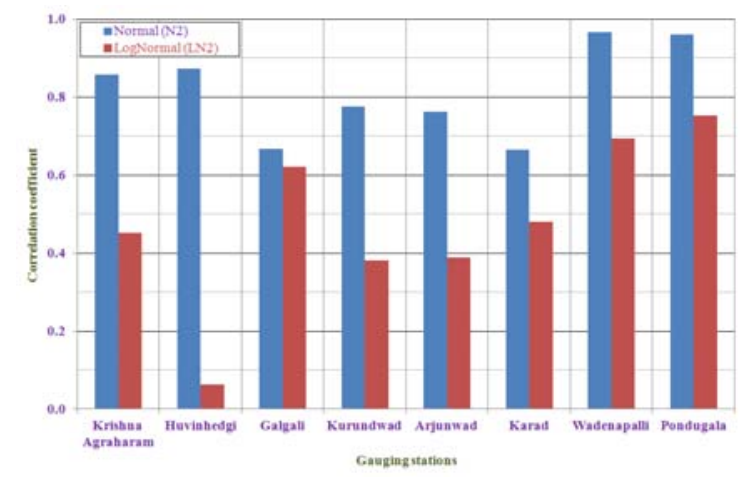

Figure 2: Correlation Coefficient of Gauging Stations based on Tran's Information Index given by N2 and LN2 Distributions

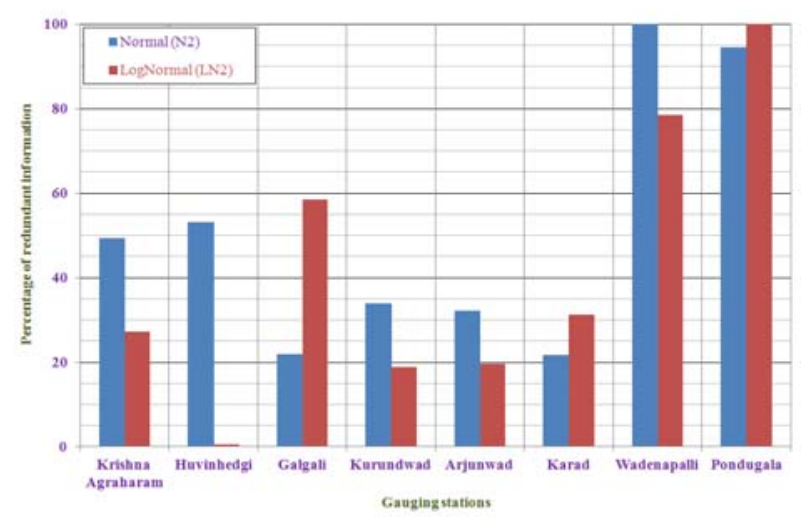


Figure 3: Percentage of Redundant Information Passed by the Station using N2 and LN2 Distributions

From the results based on contribution of information by different stations, given by N2 and LN2 distributions, it may be noted that Wadenapalli and Pondugala stations are providing more redundant information, may be singled out from the existing network for closure examination while planning to reduce the streamflow network for Krishna river basin. However, it should be noted that this is a preliminary analysis and demonstrates the application of entropy approach for network evaluation, more analysis need to be done considering all the stations for final recommendations.

\section{CONCLUSIONS}

This paper presented an entropy based procedure for evaluation of streamflow network of Krishna river basin, consists of nine stream gauging stations. The 2-parameter normal and lognormal distributions are used to represent the data and then to compute the marginal and conditional entropy indices, and the transinformation index. The results of $\mathrm{N} 2$ and LN2 distributions showed that Vijayawada station is the first priority station with highest marginal entropy for Krishna basin. The results of N2 and LN2 indicated that Wadenapalli and Pondugala stations provided $100 \%$ redundant information when N2 and LN2 distributions are used respectively; and hence considered as the reference station for computation of redundant information for other stations. From the results of transinformation index given by $\mathrm{N} 2$ and LN2 distributions, it was identified that the amount of redundant information passed by Wadenapalli and Pondugala stations are more, which may be considered for possible discontinuation of the station from the existing network while optimising streamflow network for Krishna basin.

\section{ACKNOWLEDGMENTS}

The author is thankful to the Deputy Director (Krishna and Godavari Divisions), Central Water Commission, Hyderabad, for making available the streamflow data of Krishna basin. The author is grateful to the Director, Central Water and Power Research Station, Pune, for providing the research facilities to carry out the study.

\section{REFERENCES}

[1] World Meteorological Organization (WMO, 1994). Guide to Hydrological Practices, Report No. 168, Geneva.

[2] S.P. Richard, Review and analysis of stream gauge network for the Ontario stream gauge rehabilitation project, WSC Report No. 01, 2004

[3] Jordan A. Clayton and Jason W. Kean, "Establishing a multi-scale stream gauging network in the Whitewater river basin, Kansas, USA", Water Resources Management, Vol. 24, No. 13, Pp 3641-3664, 2010.

[4] Y. Yang and D.H. Burn, "An entropy approach to data collection network design", Journal of Hydrology, Vol. 157, No. 4, Pp. 307-324, 1994

[5] S. Ozkul, N.B. Harmanucioglu and V.P. Singh, "Entropy based assessment of water quality monitoring networks", ASCE Journal of Hydrologic Engineering, Vol. 5, No. 1, Pp. 90-99, 2000.

[6] M. Markus, H.V. Knapp and G.D. Tasker, "Entropy and generalized lease square methods in assessment of the regional value of stream gauges", Journal of Hydrology, Vol. 283, Nos. 1-2, Pp 107-121, 2003.

[7] N. Sarlak and U.A. Sorman, Evaluation and selection of streamflow network stations using entropy methods, Turkey Journal of Engineering and Environmental Science, Vol. 30, No. 2, Pp. 91-100, 2006
[8] C. Yoo, K. Jung and J. Lee, "Evaluation of rain gauge network using entropy theory: Comparison of mixed and continuous distribution function applications", ASCE Journal of Hydrologic Engineering, Vol. 13, No. 4, Pp. 226-235, 2008.

[9] C.E. Shannon, A mathematical theory of communication, The Bell System Technical Journal, Vol. 27, October issue, Pp. 623-656, 1948

[10] M. Zahrani-Al and T. Hussain, "An algorithm for designing a precipitation network in the south-western region of Saudi Arabia", Journal of Hydrology, Vol. 205, Nos. 3-4, Pp. 205-216, 1998.

[11] Chao Li, V.P. Singh and A.K. Mishra, "Entropy theory-based criterion for hydrometric network evaluation and design: Maximum information minimum redundancy", Water Resources Research, Vol. 48, W05521, 15pp, DOI: 10. 1029/2011WR011251, 2012.

[12] CWC, Project report on water resources assessment of Krishna river basin, Upper Krishna Division (Central Water Commission), 83, 2000.

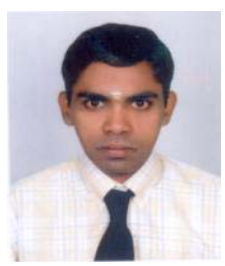

N. Vivekanandan (June 1969) post graduated in mathematics from Madurai Kamaraj University in 1991. He obtained post graduate degree in hydrology from University of Roorkee in 2000 and master of philosophy degree in mathematics from Bharathiar University in 2006. From May 1993 to March 2006, he worked as Research Assistant and analyzed hydrometeorological data using statistical methods for water related studies. From April 2006 to till date, he is working Assistant Research Officer wherein carrying out hydrological studies using statistical and deterministic approaches, prediction of hydrometeorological variables using soft computing techniques and optimization of hydrometric network using spatial regression approach and information theory for various water resources projects. 